\title{
MANAJEMEN STRATEGI DAKWAH NABI MUHAMMAD PADA MASA AWAL MADINAH
}

\author{
Dedy Pradesa \\ STID Al-Hadid, Surabaya \\ depra19312@gmail.com
}

\begin{abstract}
Abstrak. Studi ini berangkat dari keprihatinan pengelolaan organisasi dakwah yang masih tradisional, tidak didasari ilmu, salah satunya adalah ilmu manajemen strategi. Manajemen strategi telah terbukti menjadi alat yang efektif bagi keberhasilan organisasi. Termasuk dakwah Nabi Muhammad dalam salah satu periodenya, yaitu pada masa awal di Madinah. Periode tersebut dipilih karena terdapat serangkaian kebijakan dan implementasinya yang itu mengindikasikan penerapan prinsip-prinsip manajemen strategi yang tepat dan terbukti berhasil. Tujuan studi ini adalah untuk memberikan gambaran manajemen strategi dakwah Nabi Muhammad pada masa awal di Madinah. Manfaatnya diharapkan organsasi dakwah dapat mengambil contoh dan pelajaran dari hasil studi ini. Pendekatan yang digunakan adalah kualitatif historis pustaka dan expost facto. Data dikumpulkan dari sumber literatur sejarah terkait. Analisis menggunakan analisis deskriptif kualitatif historis. Hasil studi menunjukkan bahwa dalam setiap pengambilan keputusan-keputusan strategisnya, pijakan pembacaan dan analisis lingkungan sangat dominan dilakukan oleh Nabi Muhammad. Demikian pula dalam implementasi dan evaluasi strategi. Hal tersebut menunjukkan bahwa secara substansi dalam pengembangan organisasi dakwahnya Nabi Muhammad menggunakan perangkat keilmuan manajemen strategi.
\end{abstract}

Kata kunci: manajemen strategi, dakwah, masa awal Madinah

\begin{abstract}
This study starts from the apprehension about management of da'wah organization. It is traditional, not based on science one of which is management of strategy. Management of strategy has been proven to be an effective tool for the success of organization. It includes the da'wah of the prophet Muhammad in one of his period of da'wah: early period of Medina. The period is selected since there were series of policies and their implementations which indicate the application of principles of effective and well-proven management of strategy. The aim of study is to describe the prophet Muhammad's management of da'wah strategy in the early period of Medina. It is hoped that da'wah organization can take examples and wisdom from the result of study. The approach of study used is qualitative historial literature and expost facto. Data are collected from related historial literature. Its analysis uses historical qualitative historical descriptive one. The result of study shows that every strategical decision making of the prophet Muhammad was dominantly based on environmental observation and analysis. This basis was also used to implement and evaluate the strategy. It shows that the development of da'wah organization of the prophet Muhammad subtantially used management of strategy.

Key words: management of strategy, da'wah, early period of Medina
\end{abstract}




\section{Pendahuluan}

Dalam dunia bisnis, manajemen strategi telah lama terbukti menjadi tools yang efektif dalam pencapaian keunggulan kompetitif perusahaan. Keunggulan kompetitif yang dimaksud adalah segala sesuatu yang dapat dilakukan dengan jauh lebih baik oleh perusahaan bila dibandingkan dengan pesaing-pesaingnya. ${ }^{1}$ Dalam situasi lingkungan organisasi yang dinamis, pelaksanaan manajemen strategi yang tepat memungkinkan organisasi beradaptasi dalam berbagai situasi dengan tepat pula dengan tetap mempertahankan keunggulan kompetitifnya. Manajemen strategi merupakan serangkaian keputusan dan tindakan manajerial yang menentukan kinerja perusahaan dalam jangka panjang, yang meliputi pengamatan lingkungan, perumusan strategi, implementasi strategi dan evaluasi atau pengendalian. ${ }^{2}$

Dalam konteks yang demikian, maka manajemen strategi tidak hanya dibutuhkan organisasi bisnis, namun juga organisasi nonprofit, seperti organisasi dakwah. Misi dakwah secara esensi adalah aktivitas dan upaya untuk mengubah manusia, dari situasi yang tidak baik menjadi lebih baik, ${ }^{3}$ dengan nilai-nilai Keislaman. Organisasi menjadi alat untuk menjalankan misi dakwah agar dapat mencapai tujuan yang telah ditentukan secara efektif dan efisien. Keberhasilan dakwah tidak hanya diukur pada semarak aktivitas dakwah, tetapi perlu berkesinambungan dan sesuai antara

${ }^{1}$ Fred R. David, Manajemen Strategis: Konsep, Edisi 12, Buku 1, diterjemahkan Dono Sunardi, (Jakarta: Salemba Empat, 2009), 11.

2 Thomas L Wheelen \& J.D. Hunger, Manajemen Strategis, diterjemahkan Julianto Agung, (Yogyakarta: Penerbit Andi, 2006), 6.

3 M. Munir \& Wahyu Ilaihi, Manajemen Dakwah, (Jakarta: Kencana, 2006), 21. rencana, proses dan tujuan dakwah. Oleh karenanya, dakwah perlu diorganisir secara profesional dan modern. Urgensi penerapan manajemen strategi dalam organisasi dakwah tidak terlepas dari kompleksitas dan dinamika lingkungan dakwah, diperlukan upaya untuk menyelaraskan gerak organisasi dakwah dengan lingkungannya. ${ }^{4}$ Manajemen strategi menjadi sebuah kebutuhan mutlak organisasi dakwah agar mampu memetakan lingkungan internal dan eksternal secara sistematis, dan memberikan respon keputusan-keputusan strategis yang selaras dengan tuntutan lingkungannya. ${ }^{5}$

Namun realitasnya saat ini pengelolaan organisasi dakwah di Indonesia hampir jarang dilakukan secara profesional dengan menggunakan perangkat ilmu seperti manajemen strategi. Affandy menjelaskan bahwa setidaknya terdapat tiga problematika terkait hal tersebut. Pertama, pola pikir umat Islam Indonesia yang masih menganggap bahwa dakwah bersifat ruhaniah semata, sehingga tidak bisa diukur dengan indikator-indikator profesionalitas. Kedua, secara kualitas SDM umat Islam Indonesia masih tertinggal, sehingga organisasi dakwah banyak dikelola hanya dengan berbekal semangat pengabdian karena ibadah semata, tanpa diimbangi dengan ilmu dan kompetensi terkait. Ketiga, perkembangan keilmuan manajemen yang lahir dari persoalan-persoalan riil umat Islam masih sangat minim. Tidak banyak riset-riset ilmiah di bidang ilmu manajemen

${ }^{4}$ Ristiana Kadarsih \& Mohammad Zamroni, "Urgensi Manajemen Strategis dalam Pengorganisasian Dakwah," Jurnal MD, Vol.I No.1, (Juli-Desember, 2008): 80-81.

5 Shofyan Affandy, Dakwah Strategik: Sebuah Ancangan Teoritis \& Filosofis, (Suarabaya: Avvatera, 2017), 87. 
untuk menjawab masalah organsasi dakwah. ${ }^{6}$

Beberapa penelitian penerapan manajemen strategi di beberapa organisasi sosial Islam atau dakwah mendukung pendapat tersebut. Pertama, hasil penelitian dari Ajrin yang menyimpulkan bahwa esensi dan penerapan manajemen strategi salah satu lembaga Islam di Kota Bima belum menunjukkan keberhasilan sepenuhnya dalam proses pembelajaran dan peningkatan dakwahnya sehingga masih perlu perbaikan dan lebih progresif lagi dalam melaksanakan kegiatan atau pelatihan dakwanya. ${ }^{7}$ Kedua, penelitian dari Harmoyo terkait analisis manajemen strategis di salah satu Baitul Mal wat Tamwil (BMT), yang menjelaskan bahwa banyak BMT yang dikelola ala kadarnya tanpa memperhatikan faktor-faktor lingkungannya guna merumuskan manjemen stratategi yang baik. ${ }^{8}$ Ketiga, studi dari Muzayin terhadap Lembaga Pendidikan Dakwah Masjid Agung di salah satu kota di Jawa Timur menyebutkan bahwa dalam proses manajemen kelembagaannya masih perlu banyak berbenah diri dan berusaha meningkatkan tahap demi setahap. ${ }^{9}$ Artinya proses penerapan manajemen strategi lembaga dakwah dalam mencapai tujuannya masih belum berjalan secara optimal. Dampaknya adalah organisasi dakwah tidak cukup kompetitif, terlebih

\footnotetext{
${ }^{6}$ lbid., 182-185.

7 Muhammad Ajrin, "Manajemen Strategi dalam Mengelola Dakwah pada Pesantren Al-Husainy di Kota Bima" (Skripsi, UIN Alaudin Makasar, 2017), 74.

8 Dwi Harmoyo, "Analisis Manajemen Strategis Koeprasi Jasa Keuangan Syariah Baitul Mal wat Tamwil Syariah Sejahtera Boyolali" (Thesis, STAIN Surakarta, 2011), 5.

9 Arif Muzayin, "Studi Manajemen Lembaga Pendidikan Dakwah di Masjid Agung Kota Blitar,"
}

dalam situasi persaingan dan lingkungan milenial saat ini.

Sejatinya telah terdapat contoh keberhasilan penerapan manajemen strategis di lapangan organisasi dakwah, yang dilaksanakan oleh Nabi Muhammad saw. Sekalipun di eranya, ilmu manajemen strategi belum dikenal, namun keberhasilan Nabi Muhammad dalam pengembangan dakwahnya tidak lepas dari keputusankeputusan strategis yang dihasilkannya, sehingga dapat memiliki keunggulan kompetitif terhadap pesaing-pesaingnya dan mencapai misi dakwah Islam. Dari sudut pandang manajemen strategi, setiap keputusan strategis yang dihasilkan Nabi Muhammad di segala macam kondisi lingkungan internal dan eksternal dakwahnya sesuai dengan ilmu manajemen strategi yang modern. ${ }^{10} \quad \mathrm{Di}$ sinilah pentingnya umat Islam khususnya pelaku dakwah hari ini untuk mengkaji sejarah perjuangan dakwah Nabi Muhammad dalam perspektif manajemen strategi. Dari situ, dapat dipahami bahwa dalam dakwahnya, Nabi Muhammad tidak dilakukan ala kadarnya, setiap keputusankeputusan dipertimbangkan secara mendalam sesuai dengan keadaan lingkungan yang dihadapi. Dengan kata lain, keberhasilan dakwah Nabi Muhammad salah satunya adalah karena menerapkan manajemen strategi.

Jurnal Kajian dan Pengembangan Manajemen Dakwah, Volume 04 Nomor 01 (Juni 2014):83-101, 100.

10 Walid Fajar Antariksa, "Penerapan Manajemen Strategi dalam Dakwah Nabi Muhammad, saw.," Jurnal Manajemen Pendidikan Islam, Volume 2, nomor 1 (Juni 2017):28-37 , 37. DOI: http://dx.doi.org/10.188860/impi.v2i1.4357 
Berangkat dari fenomena permasalahan di atas, studi ini mengkaji manajemen strategi yang dilakukan oleh Nabi Muhammad dalam organisasi dakwahnya. Studi ini memfokuskan pada masa awal dakwah Nabi Muhammad di Madinah. Masa awal yang dimaksud dibatasi pada tahun pertama dan kedua setelah hijrah. Sebagaimana diketahui, dakwah Nabi mengalami situasi sulit dan tidak memungkinkan lagi untuk dilanjutkan ketika di Makkah. Untuk itu Nabi Muhammad beserta umat Islam Makkah melakukan hijrah ke Yatsrib, yang kemudian diberi nama Madinah. Masa awal di Madinah adalah masa-masa kritis yang menentukan, sebab organisasi dakwah Islam belum sepenuhnya mapan, kesatuan umat juga belum terbentuk utuh, ancaman dari kaum kafir Quraisy Makkah juga masih besar, ditambah lagi ancaman dari sebagian penduduk Madinah yang tidak sepakat dengan dakwah Nabi Muhammad. Untuk itu diperlukan keputusan-keputusan strategis yang tepat dalam menghadapi berbagai situasi tersebut. Nabi Muhammad dapat dikatakan berhasil, terbukti organisasi dakwahnya dapat berkembang di Madinah dan memiliki keunggulan kompetitif sehingga mampu mengalahkan pesaingpesaingnya dan mencapai misi dakwahnya.

Situasi-situasi kritis serupa dengan masa dakwah awal di Madinah dapat juga dihadapi oleh organisasi dakwah pada hari ini. Misalnya ketika dihadapkan pada lingkungan dakwah yang baru, keadaan internal organisasi yang belum mapan, sementara pesaing sangat kuat, sehingga diperlukan arah kebijakan strategis yang tepat untuk menghadapi situasi tersebut. Kajian manajemen strategi dakwah Nabi Muhammad di masa awal Madinah dapat menjadi pelajaran penting bagi organisasi dakwah yang menghadapi situasi serupa.

Fokus masalah dalam studi ini adalah deskripsi penerapan manajemen strategi dalam dakwah Nabi Muhammad di masa Madinah awal. Masa Madinah awal yang dibatasi pada tahun pertama dan kedua setelah hijrah. Pertanyaan-pertanyaan pokok yang hendak ditelusuri adalah bagaimana situasi lingkungan yang dihadapi organisasi dakwah Nabi Muhammad kala itu? Apa saja keputusan-keputusan strategis yang diambil oleh Nabi Muhammad untuk menghadapi situasi tersebut? Bagaimana keterkaitan keputusan tersebut dengan pembacaan dan analisis lingkungan? Bagaimana keputusan tersebut diimplementasikan? Serta adakah pengendalian dan evaluasi strategi? Dengan demikian tujuan dari studi ini secara umum adalah untuk memberikan gambaran dakwah Nabi Muhammad di masa Madinah awal dalam perspektif manajemen strategis. Tujuan secara khusus adalah untuk mendeskripsikan: (a) situasi atau lingkungan strategis yang dihadapi Nabi ketika itu; (b) keputusan-keputusan strategis yang diambil dan keterkaitannya dengan situasi strategis tersebut; (c) implementasi keputusan strategis tersebut; (d) evaluasi dan pengendalian strategi. Manfaat yang diharapkan dari hasil studi ini, secara teoritis akan memperkaya kajian terhadap sejarah dakwah Nabi Muhammad dalam perspektif yang relatif jarang dilakukan yaitu pendekatan manajemen strategis. Secara praktis, hasil studi diharapkan dapat memberikan keyakinan dan inspirasi bagi para pelaku dakwah untuk menerapkan manajemen strategi dalam dakwahnya. 
Penelusuran terhadap literatur terdahulu menunjukkan tidak banyak studi yang mengkaji sejarah dakwah Nabi Muhammad dalam perspektif manajemen strategi. Beberapa studi terkait yang ditemukan di antaranya adalah, pertama, artikel jurnal "Penerapan Manajemen Strategi dalam Dakwah Nabi Muhammad, saw."11 Artikel tersebut berusaha menguraikan bagaimana manajemen strategi yang diterapkan oleh Nabi Muhammad saw. dalam keseluruhan dakwahnya. Studi tersebut membagi empat fase dakwah Nabi Muhammad dalam empat fase, yaitu Makkah awal, Makkah akhir, Madinah awal, dan Madinah akhir. Kemudian menganalisis empat kondisi tersebut berdasarkan analisis kekuatan, kelemahan, peluang, dan ancaman (Strenght, Weakness, Opportunity, Threat [SWOT Analysis]), yang menghasilkan empat kuadran kondisi lingkungan dakwah Nabi Muhammad yang berkesesuaian dengan empat fase dakwah tersebut. Dalam artikel tersebut tidak diuraikan analisis tiap keputusan strategis dalam tiap fase yang dikaitkan dengan hasil pemetaan lingkungan, serta keunggulan kompetitif apa yang berhasil dicapai organisasi dakwah Nabi dalam tiap fase. Dalam hubungannya dengan studi ini, maka artikel tersebut dapat menjadi pijakan umum memahami situasi strategis dakwah Nabi pada masa awal di Madinah. Perbedaannya studi ini secara spesifik membahas penerapan manajemen strategi di masa awal Madinah. Analisis diarahkan kepada keputusankeputusan strategis Nabi Muhammad dalam menghadapi lingkungan dakwahnya serta

11 lbid.

12 Yuana Ryan Tresna, Muhammad saw on The Art of War: Manajemen Strategi Peperangan Rasulullah saw, (Bandung: Progressio, 2006). usaha pencapaian keunggulan kompetitif di masa awal Madinah. Kedua, buku berjudul Muhammad saw on The Art of War: Manajemen Strategi Peperangan Rasulullah saw. ${ }^{12}$ Buku tersebut secara khusus membicarakan peperangan Rasulullah dalam perspektif manajemen strategi. Kerangka manajemen strategi sebagai sebuah tools dalam peperangan sangat dominan dalam pembahasannya. Sehingga berbeda dengan studi ini, yang membahas pada masa Madinah awal, dimana perang belum menjadi keputusan strategis ketika itu.

Studi ini menggunakan pendekatan kualitatif pustaka historis. Kualitatif karena tujuan dari studi ini memahami fenomena secara holistik tentang apa yang dialami subjek penelitian. ${ }^{13}$ Pustaka historis karena proses pengumpulan data menggunakan sumber-sumber kepustakaan sejarah terkait. Studi ini juga merupakan studi expost facto atau penelusuran kembali, ${ }^{14}$ karena variabel-variabel peristiwa yang diteliti sudah terjadi. Data dikumpulkan dengan membaca dan mencatatnya dari sumber-sumber sejarah yang digunakan, yaitu: (1) Sirah Nabawiyah karya Ibnu Ishaq \& Ibnu Hisyam; (2) Sejarah Hidup Muhammad karya M. Husain Haekal; (3) Sirah Nabawiyah karya Al-Mubarakfuri; (4) Muhammad The Prophet karya M. Ali; (5) Muhammad sebagai Manusia dan Nabi karya Salahi; (6) Manhaj Haraki - Strategi Pergerakan dan Perjuangan Politik dalam Sirah Nabi Saw. karya Al-Ghadban; (7) Muhammad (Kisah Hidup Nabi berdasarkan

\footnotetext{
13 Lexy J. Moleong, Metodologi Penelitian Kualitatif, Cetakan ketigapuluhempat, (Bandung: Rosda, 2015), 6.

${ }^{14}$ Sukardi, Metodologi Penelitian Pendidikan, (Jakarta: Bumi Aksara, 2012), 165.
} 
Sumber Klasik) karya Martin Lings; (8) Membaca Sirah Nabi Muhammad saw. dalam sorotan Alquran dan Hadis Shahih karya Quraisy Shihab; (9) Muhammad Biografi Sang Nabi karya Karen Armstrong; (10) Muhammad Sang Negarawan karya Montomery Watt. Keseluruhan sumbersumber di atas membicarakan fase dakwah Nabi Muhammad ketika di Madinah, sehingga relevan digunakan dalam studi ini. Analisis data secara kualitatif historis, dengan memadukan model Miles dan Huberman, ${ }^{15}$ dan analisis historis. Data dikumpulkan, seleksi, dan sajikan sesuai unit analisis manajemen strategi dalam bentuk narasi historiografis yang didukung dengan sketsa dan tabel. Penyimpulan dilakukan dengan analisis logis dan interpretasi data sejarah dalam kerangka manajemen strategi organisasi dakwah.

\section{Manajemen Strategis Organisasi Dakwah}

\section{Konsep Manajemen Strategis}

Manajemen strategis diperlukan untuk menghadapi dinamika lingkungan organisasi. Organisasi yang baik akan segera tertinggal jika gagal beradaptasi terhadap perubahan lingkuangan atau bahkan gagal menciptakan perubahan. ${ }^{16}$ Keunggulan kompetitif organisasi hanya dapat dicapai dengan cara terus menerus beradaptasi pada perubahan serta merumuskan, menerapkan, dan menilai secara efektif berbagai strategi untuk menguatkan faktorfaktor keunggulan kompetitif organisasi. ${ }^{17}$

15 Ismail Nawawi, Metode Penelitian Kualitatif, (Jakarta: Dwiputra Pustaka, 2012), 256-259.

16 Hunger \& Wheelen, Manajemen Strategis., 2-3.

17 David, Manajemen Strategis., 11-13.

18 John A. Pearce \& Richard B. Robinson, Manajemen Strategis: Formulasi, Implementasi, dan
Proses manajemen startegi dilakukan dengan cara menempatkan organisasi secara optimal di lingkungan persaingannya dengan memaksimalkan antisipasi terhadap lingkungan dan tuntutan intern serta persaingan yang seringkali tak terduga. ${ }^{18}$ Proses manajemen strategi dapat dibagi dalam tahap-tahap berikut: (a) tahap pemetaan dan perumusan strategi; (b) tahap implementasi/pelaksanaan strategi; (c) tahap evaluasi dan pengendalian strategi. ${ }^{19}$

Pertama, pemetaan dan perumusan strategi, mencakup pengembangan visi misi, identifikasi peluang dan ancaman eksternal, identifikasi kekuatan dan kelemahan internal, penetapan tujuan jangka panjang, perumusan alternatif strategi dan pemilihannya. Tahap perumusan strategi berarti pengembangan rencana jangka panjang untuk manajemen efektif berbasis pada hasil pengamatan lingkungan, meliputi evaluasi interaksi antar faktor strategis, penentuan misi, penentuan tujuan, strategi dan kebijakan. Pengembangan visi misi organisasi dimaksudkan untuk menjadi dasar dan arah dalam perumusan strategi, oleh karenanya visi misi organisasi harus jelas. Pemetaan terkait pengamatan lingkungan organisasi yaitu mengidentifikasi faktor-faktor strategis berupa analisis lingkungan eksternal yang menghasilkan variabel-variabel peluang (oportunity) dan ancaman (threat), dan analisis lingkungan internal yang menghasilkan identifikasi variabel-variabel kekuatan (strenght) dan kelemahan (weakness), khususnya pada

Pengendalian, Edisi 12 Buku 1, diterjemahkan Nia Pramitasari (Jakarta: Salemba Empat, 2013), 19.

19 David., Manajemen Strategis. 6; Hunger \& Wheelen, Manajemen Strategis., 9. 
wilayah struktur organisasi, budaya organisasi, dan sumber daya organisasi. ${ }^{20}$ Prinsip dari perumusuan strategi adalah mengambil keuntungan dari peluang eksternal, dan menghindari atau meminimalkan dampak ancaman eksternal, serta menggandakan kekuatan internal sekaligus meniadakan kelemahan internal. Tujuan jangka panjang merepresentasikan hasil-hasil yang diharapkan dari pelaksanaan strategi tertentu. Tujuan tersebut bisa bersifat keuangan (organisasi bisnis), bisa bersifat strategis, seperti penguasaan pasar dan kompetitor. ${ }^{21}$ Analisis dan pemilihan strategi berusaha menentukan tindakan alternatif yang paling baik dalam membantu perusahaan mencapai misi dan tujuannya. Strategi, tujuan, dan misi perusahaan, ditambah dengan informasi penilaian internal dan eksternal memberikan landasan untuk menciptakan serta mengevaluasi program kerja alternatif yang masuk akal. ${ }^{22}$ Alternatif formulasi strategi dapat dikelompokkan sebagai berikut: (a) strategi diversifikasi atau pengembangan usaha; (b) strategi integrasi; (c) strategi deintegrasi; (d) strategi intensifikasi yakni penetrasi pasar, prngrmbangan pasar, produk, dan inovasi; (e) strategi defensif; (f) strategi kooperatif; (g) strategi berkembang, yang terdiri dari merger dan akuisisi; (h) srategi khusus dan kombinasi. ${ }^{23}$

Kedua, tahap penerapan strategi, yang berarti mewujudkan strategi dan kebijakan

\footnotetext{
${ }^{20}$ Hunger \& Wheelen, Manajemen Strategis., 9-10.

21 David., Manajemen Strategis; 244.

22 Ibid., 270.

23 Jemsly Hutabarat \& Martani Huseini, Strategi Pendekatan Komprehensif dan Terintegrasi "Strategic Excellence" dan "Operational Excellence" secara Simultan (Jakarta: Penerbit UI, 2011), 193.

${ }^{24}$ Hunger \& Wheelen, Manajemen Strategis., 10-19.
}

dalam tindakan atau aktivitas seperti penyusunan program, anggaran, dan prosedur. ${ }^{24}$ Penerapaan strategi meliputi penetapan tujuan tahunan, kebijakan program, prosedur, dan anggaran, pemotivasi SDM, serta alokasi sumber daya untuk menjalankan strategi. ${ }^{25}$ Implementasi strategi bertumpu pada alokasi dan pengorganisasian sumber daya manusia yang ditampakkan melalui penetapan struktur organisasi, mekanisme kepemimpinan yang dijalankan berikut budaya organisasi. ${ }^{26}$ Ketiga, Tahap evaluasi dan pengendalian strategi berarti proses memonitor dan aktivitas organisasi dan membandingkan hasil kinerja dengan yang diharapkan, yang hasilnya menjadi bahwan evaluasi bagi keseluruhan proses manajemen strategi. ${ }^{27}$ Evaluasi atau penilaian tersebut meliputi peninjauan ulang faktor eksternal dan internal yang menjadi landasan strategi, pengukuran kinerja, dan pengambilan langkah korektif. ${ }^{28}$

\section{Dakwah dan Lingkungan Organisasi Dakwah}

Dakwah dalam Alquran dapat dikatakan sebagai usaha bersama umat Islam sesuai dengan tingkat kemampuannya untuk menjadikan manusia menerima Islam secara baik, dengan disertai metode yang mulia demi tercapainya kebahagiaan dunia dan akhirat. ${ }^{29}$ Sebagai usaha bersama maka kegiatan dakwah perlu diorganisir dan dimanajemen. Organisasi dakwah adalah alat untuk mencapai misi dakwah tersebut,

\footnotetext{
25 David., Manajemen Strategis; 391-396.

26 Muhammad Ismail Yusanto dan M. Karebet Widjayakusuma, Manajemen Strategis Perspektif Syari'ah (Jakarta: Khairul Bayan, 2003), 92.

27 Ibid., 11-19.

28 David., Manajemen Strategis., 6-7.

29 Aswadi, Dakwah Progresif Perspektif Alquran, (Sidoarjo: Dwiputra Pustaka Jaya, 2016), 145.
} 
sedangkan manajemen dakwah merupakan pengaturan secara sistematis dan koordinatif dalam kegiatan atau aktivitas dakwah yang dimulai dari sebelum pelaksanaan sampai akhir dari kegiatan dakwah. ${ }^{30}$ Dalam manajemen dakwah komponen dakwah diuraikan ke dalam beberapa unsur yang perlu untuk dikelola guna mencapai tujuan dakwah, yaitu antara lain dai (pelaku dakwah), mad'uw (sasaran/objek dakwah), maddah (materi dakwah), wasilah (media dakwah), thariqah (metode dakwah), dan atsar (efek dakwah). ${ }^{31}$ Lingkungan terkait keadaankeadaan di internal dan eksternal organisasi yang berpotensi memengaruhi kinerja organisasi dalam mencapai tujuannya. Setiap organisasi senantiasa menghadapi dinamika atau perubahan dari lingkungan tersebut. Demikian pula organisasi dakwah, juga akan menghadapi dinamika lingkungan dakwah. Lingkungan dakwah yang dimaksud adalah lingkungan internal dan eksternalnya. Lingkungan internal terkait keadaan sumber daya manusia (SDM) dakwah, produk atau materi yang didakwahkan, metode dan media yang digunakan, serta sistem manajemen dan budaya organisasi dakwah. Lingkungan eksternal terkait keadaan pasar atau sasaran mitra dakwah, keadaan pesaing dakwah, situasi sosial, politik, dan ekonomi yang melingkupi organisasi dakwah.

\section{Manajemen Strategis Organisasi Dakwah}

Manajemen strategi organisasi dakwah berarti serangkaian keputusan dan tindakan

\footnotetext{
30 M. Munir, Manajemen Dakwah, (Jakarta: Kencana, 2006), 36-37.

31 Ibid., 21.
}

manajerial yang menentukan kinerja organisasi dakwah dalam jangka panjang untuk mencapai visi dan misi dakwahnya. Keputusan-keputusan strategis yang diambil tidak boleh bertentangan dengan etika dakwah. Etika dakwah yang dimaksud adalah sebagaimana dalam jalan dakwah universal para Rasul, yaitu: (1) tidak dilakukan dengan segala cara, (2) tidak boleh mengikuti jalan hidup orang-orang musyrik, (3) disampaikan dengan jelas dan terbuka, (4) sekedar menyampaikan dan tidak memaksa. ${ }^{32}$ Keputusan strategis juga harus sejalan dengan asas-asas strategi dakwah, yaitu: (1) asas filosofis, terkait dengan tujuan dakwah, (2) asas sosiologis dan psikologis, terkait keadaan mitra dakwah, (3) asas kemampuan pelaku dakwah, (4) asas efektivitas dan efisiensi strategi. ${ }^{33}$ Keunggulan kompetitif dalam konteks manajemen strategi organisasi dakwah berarti segala sesuatu yang dapat dilakukan dengan jauh lebih baik oleh organisasi dakwah dari pada pesaing-pesaingnya. Segala sesuatu tersebut setidaknya mencakup unsur-unsur dakwah, mulai dari pelaku dakwah, materi dakwah, media, metode, dan mitra dakwah. Pada dasarnya kerangka kerja manajemen strategi organisasi dakwah tidak jauh berbeda dengan proses manajemen strategi sebagaimana di atas. Kerangka kerja manajemen strategi pada umumnya masih memberikan ruang yang sangat luas bagi infiltrasi paradigma dan nilai-nilai apapun tanpa harus membongkarnya, sehingga akan kompatibel untuk diadaptasikan dengan berbagai motif dan tujuan

\footnotetext{
32 Iskandar Al-Warisyi, Dakwah Illahiah (Surabaya: Penerbit Yayasan Al-Kahfi, 2009), 118-119.

${ }^{33}$ Asmuni Syukur, Dasar-Dasar Strategi Dakwah Islam (Surabaya: Al-Ikhlas, 1983), 32-33.
} 
organisasi. ${ }^{34}$ Paradigma (visi misi dakwah) dan nilai-nilai dalam dakwah menjadi dasar dalam keseluruhan proses manajemen strategi organisasi dakwah. Dengan demikian kerangka kerja manajemen strategi organisasi dakwah terdiri atas tahapan: (a) pemetaan lingkungan internal dan eksternal organisasi dakwah; (b) perumusan strategi organisasi dakwah berdasarkan hasil pemetaan lingkungan organisasi dakwah; (c) implementasi strategi organisasi dakwah; (d) evaluasi dan pengendalian strategi organisasi dakwah. Berikut gambar sketsa proses manajemen strategis dalam konteks organisasi dakwah:

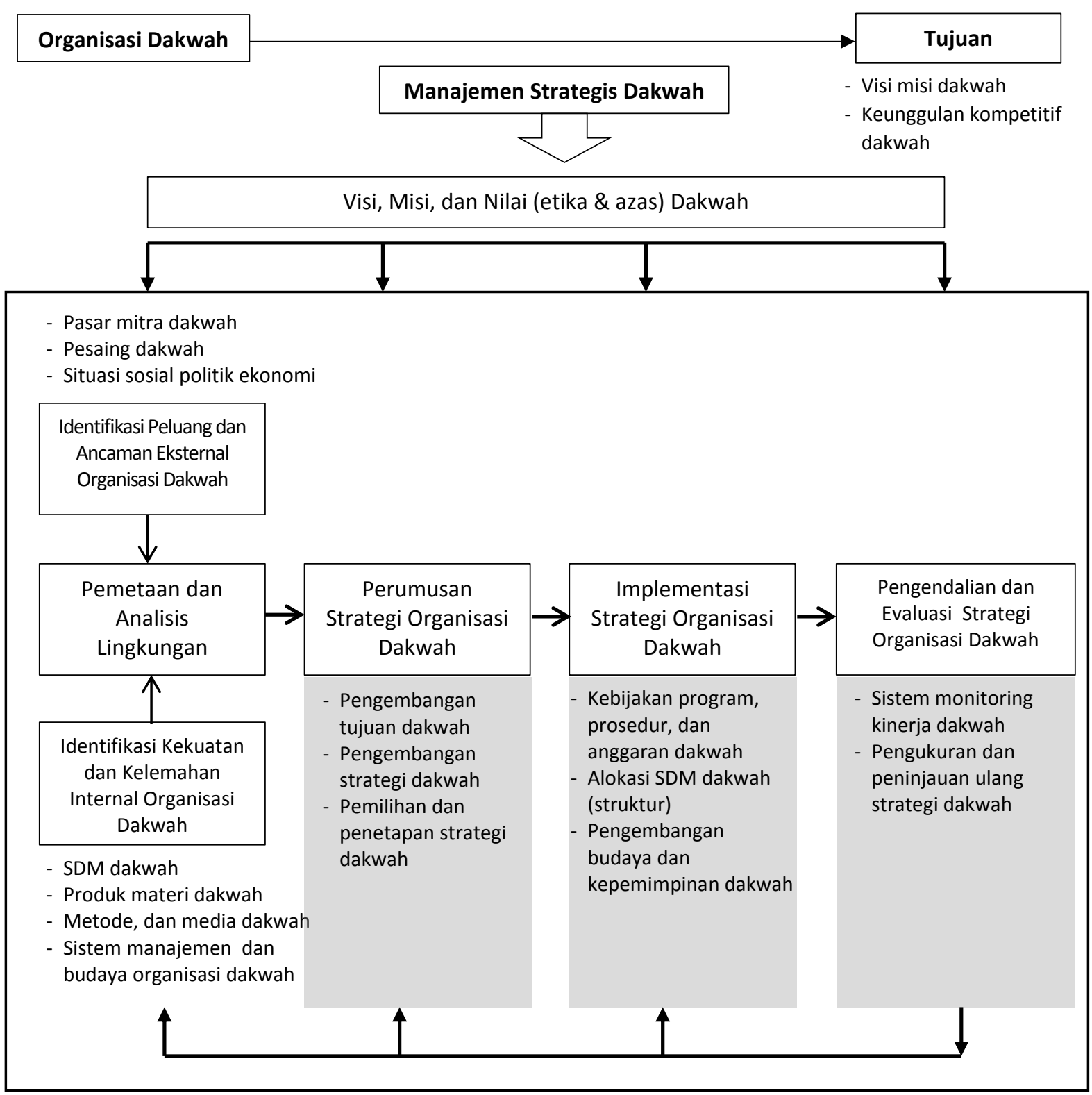

Gambar 1 - Kerangka Kerja Manajemen Strategis Organisasi Dakwah

${ }^{34}$ Affandy, Dakwah Stratejik., 180. 
Studi ini hendak mendeskripsikan manajemen strategi organisasi dakwah Nabi Muhammad pada masa awal dakwah di Madinah, yaitu sekitar tahun pertama dan kedua setelah hijrah. Kerangka kerja di atas menjadi panduan umum untuk memahami peristiwa tersebut. Sehingga unit analisis dalam studi ini mencakup, pertama, deskripsi lingkungan strategis (sebagai hasil pemetaan dan analisis) yang dihadapi organisasi dakwah Nabi pada masa awal di Madinah. Lingkungan strategis tersebut meliputi keadaan internal dan eksternal organisasi dakwah. Kedua, keputusankeputusan strategis dalam organisasi dakwah Nabi sebagai hasil dari perumusan strategi atas dasar analisis lingkungan internal dan eksternal. Dalam hal ini akan dideskripsikan berbagai keputusan strategis dakwah Nabi dan dianalisis keterkaitannya dengan situasi lingkungan organisasi dakwah pada masa awal di Madinah. Ketiga, bentuk implementasi keputusan strategis tersebut, yang mencakup berbagai kebijakan program, prosedur atau teknis pelaksanaan, dan anggaran; alokasi SDM; pengembangan budaya organisasi, dan kepemimpinan dalam organisasi dakwahnya. Keempat, deskripsi pengendalian dan evaluasi strategi yang telah ditetapkan dan dilaksanakan dalam organisasi dakwah Nabi pada masa awal di Madinah. Sebelumnya akan dideskripsikan terlebih dahulu situasi sosial dakwah Nabi pada masa sebelum dan awal di Madinah

35 Martin Lings, Muhammad Kisah Hidup Nabi Berdasarkan Sumber Klasik, diterjemahkan Qomaruddin, (Jakarta: Serambi Ilmu Semesta, 2008), 182.; Syaikh Shafiyyurahman Al-Mubarakfuri, Sirah Nabawiyah, diterjemahkan Kathur Suhardi, (Jakarta: Pustaka Al-Kautsar, 1997), 129.; M Husein Haekal, Sejarah Hidup Muhammad, 1965, diterjemahkan oleh Ali Audah (Jakarta: Litera AntarNusa: 2008), 152. sebagai konteks umum yang melingkupi peristiwa yang dikaji.

\section{Situasi Sosial Dakwah Nabi Sebelum dan Masa Awal di Madinah}

Sebelum hijrah ke Madinah, Nabi telah berdakwah dan membangun organisasinya selama tiga belas tahun di Makkah. Dakwah di Makkah sungguh berat, tekanan datang dari mayoritas pemuka masyarakat Makkah, Suku Quraisy. Mereka menolak produk dakwah yang ditawarkan Nabi Muhammad dengan keras. Mereka menyiksa pengikut Nabi Muhammad yang lemah, melakukan pemboikotan ekonomi, sampai ancaman dan tekanan fisik secara langsung kepada Nabi. ${ }^{35}$ Situasi tersebut, membuat Nabi Muhammad mencoba untuk mencari tempat baru sebagai pusat dakwah. Awalnya Nabi mencoba mengalihkan dakwahnya di kota tetangga Makkah, yaitu Thaif, namun gagal. Namun Nabi tidak berhenti berdakwah, berbagai peluang coba diambil. Salah satunya adalah dengan memanfaatkan musim haji di Makkah. Nabi mendatangi berbagai kabilah dari luar Makkah untuk didakwahi pada saat musim haji. ${ }^{36}$ Dari proses itulah, akhirnya Nabi bertemu dengan orang-orang dari Yatsrib (Madinah) yang tertarik dengan produk dakwah Nabi. Mereka kemudian menyatakan masuk Islam dan menyatakan kesiapannya untuk melindungi Nabi, melalui Baiat Aqabah. ${ }^{37}$ Perkembangan situasi

\footnotetext{
36 Syaikh Munir Muhammad Al-Ghadban, Manhaj Haraki Strategi Pergerakan dan Perjuangan Politik dalam Sirah Nabi Saw., diterjemahkan Aunur Rafiq Shalih, Afsuri dan Anshori Umar S., (Jakarta: Robbani Press, 2009), 176-180, 192-193.; Al-Mubarakfuri, Sirah, 148-149, 155-156

37 Al-Mubarakfuri, Sirah, 170-175.; Haekal, Sejarah, 173-177.
} 
membuat Nabi memutuskan agar umat Islam Makkah hijrah ke Madinah. Sekalipun tidak mudah, Nabi dan umat Islam Makkah akhirnya bisa selamat sampai di Madinah.

Secara sosiologis, Madinah berbeda dengan Makkah. Di Madinah, agama-agama, kebudayaan-kebudayaan dan komunitaskomunitas yang berbeda hidup berdampingan untuk memberikan kekayaan dan warna tertentu dalam kehidupan sosialnya. Sementara Makkah memiliki agama dan komunitas tunggal. Dua suku Arab terbesar di Madinah adalah Aus dan Khazraj. Selain itu juga terdapat kelompokkelompok orang Yahudi, dengan tiga suku utama, yaitu Bani Qainuqa, Bani Nadhir, Bani Quraizah. Madinah merupakan wilayah subur, perekonomian penduduknya berbasis pertanian. Sebagian kecil menjalankan perdagangan, dan perindustrian, yang didominasi oleh orang Yahudi. Dalam menjalankan perdagangannya, orang-orang Yahudi seringkali menggunakan sistem riba. Hal tersebut memungkinkan mereka untuk mengeksploitasi pasar, dan menjamin posisi keuangannya. Karena itulah banyak penduduk Madinah membencinya. Namun antara Aus dan Khazraj sendiri terlibat dalam beberapa pertempuran, yang pertama dikenal sebagai Perang Samir, dan yang terakhir Perang Buats, terjadi lima tahun sebelum kedatangan Nabi. Orang Yahudi memainkan peran penting dalam memicu terjadinya permusuhan antara Aus dan Khazraj. Orang Yahudi juga sering

\footnotetext{
${ }^{88}$ M.A. Salahi, Muhammad sebgai Manusia dan Nabi, diterjemahkan M. Sadat Ismail, (Yogyakarta: Mitra Pustaka, 2010), 244-251.

39 Lings, Muhammad, 227.

${ }^{40}$ Ibnu Ishak \& Ibnu Hisyam, M. Husein Haekal, Martin Lings, Al-Mubarakfury, K. Armstrong, M.Watt.
}

menyombongkan pengetahuan mereka tentang agama, hukum-hukum, dan tentang akan datangnya Nabi akhir zaman. Tatanan keagamaan penduduk Madinah (selain Yahudi dan Nasrani) praktis ditentukan oleh Quraisy, sebagaimana wilayah Arab lainnya yang mengikuti praktik keagamaan mereka yang menyembah berhala. ${ }^{38}$

Ketika Nabi tiba di Madinah, berbagai kabar menyatakan bahwa penduduk Madinah sudah tidak sabar menunggu kedatangan beliau di sana. ${ }^{39}$ Dari catatan para sejarahwan, terdapat beberapa peristiwa penting yang dilakukan Nabi Muhammad dan umat Islam pada masa-masa awal di Madinah, yaitu: (1) pembangunan masjid; (2) mempersaudarakan kaum Anshar dan Muhajirin; (3) perjanjian dengan penduduk Madinah (Piagam Madinah), termasuk perjanjian dengan orang-orang Yahudi; (4) sarriyah (pengintaian dan penyergapan) terhadap kafilah dagang Quraisy; (5) pemindahan kiblat dari menghadap Baitul Maqdis ke Kakbah; ${ }^{40}$ Sementara Shihab menambahkan kegiatan (6) pembangunan pasar; dan (7) melakukan sensus penduduk muslim. ${ }^{41}$ Selain itu, pada masa awal di Madinah, Nabi juga melangsungkan pernikahannya dengan Aisyah, putri Abu Bakar. Salah satu kegiatan sariyyah, yang dipimpin langsung oleh Nabi untuk menyergap kafilah dagang Quraisy yang dipimpin oleh Abu Sofyan berujung pada peristiwa Perang Badar pada tahun kedua hijriah, yang dimenangkan oleh umat Islam. ${ }^{42}$ Pasca itu posisi organisasi dakwah

41 M. Qurasih Shihab, Membaca Sirah Nabi Muhammad Saw. dalam Sorotan Alquran dan HadisHadis Shahih, (Tangerang: Lentera Hati, 2012), 516520.

${ }^{42}$ Ibnu Ishaq \& Ibnu Hisyam, Sirah Nabawiyah Sejarah Lengkap kehidupan Rasulullah, tt, diterjemahkan oleh 
Nabi di Madinah semakin kokoh. Masa konsolidasi awal di Madinah dapat dilalui dengan baik oleh Nabi Muhammad.

\section{Manajemen Strategi Dakwah pada Masa Awal Madinah}

Keberhasilan Nabi dalam melakukan konsolidasi pada masa awal di Madinah dengan berbagai kebijakan-kebijakan strategis adalah indikasi dari adanya strategi yang dimanajemen sedemikian rupa, dengan menyesuaikan dinamika lingkungan dakwah yang dihadapi organisasi Nabi kala itu. Masa tahun pertama dan kedua di Madinah adalah masa yang menentukan bagi perkembangan organisasi dakwah Nabi. Dan terbukti dalam sejarah, pada tahun-tahun selanjutnya dakwah Nabi semakin berkembang, Nabi memiliki kedudukan yang semakin kokoh di Madinah, dan penduduk Makkah pun dapat ditaklukkan dan menerima Islam pada tahun kedelapan setelah hijrah. Sebagaimana tahapan manajemen strategis pada umumnya, yaitu pemetaan dan analisis lingkungan dakwah, perumusan strategi dakwah, implementasi, dan evaluasi strategi, manajemen strategi dakwah yang dilakukan oleh Nabi juga tidak terlepas dari tahapan tersebut. Artinya Nabi melakukan pemetaan dan analisis lingkungan situasi awal di Madinah, Nabi merumuskan dan menetapkan kebijakan-kebijakan strategis dakwah untuk menyikapi situasi lingkungan yang dihadapinya, Nabi mengatur sumber daya yang dimilikinya untuk mengimplementasikan strateginya, serta melakukan evaluasi terkait dinamika lingkungan yang dihadapi, perubahan kebijakan strategis, dan implementasinya. Tanpa melakukan proses itu semua, akan sulit bagi Nabi untuk berhasil dalam dakwahnya pada masa-masa awal di Madinah. Tahapan manajemen strategis yang dilakukan Nabi, tentunya tidak bersifat statis, melainkan dinamis, mengikuti perubahan dan perkembangan lingkungan internal dan eksternal yang dihadapinya. Hal tersebut dapat diketahui dari adanya perubahan beberapa keputusan strategis dalam dakwah pada masa awal di Madinah. Untuk itu akan diuraikan lebih jauh bagaimana proses manajemen strategis dakwah Nabi pada masa awal di Madinah, mulai dari pemetaan dan analisis lingkungannya, sampai dengan pengendalian dan evaluasi strateginya, serta keunggulan kompetitif yang berhasil dicapai.

1. Pemetaan dan Analisis Lingkungan Strategi Dakwah Nabi pada Masa Awal Madinah

Terdapat indikasi-indikasi yang menunjukkan bahwa Nabi melakukan pemetaan lingkungan, pertama, sebelum Nabi dan umat Islam Makkah hijrah ke Madinah, terlebih dahulu Nabi telah mengirimkan sahabatnya, Mushab bin Umair, yang ditugaskan untuk mengajarkan Islam pada penduduk Madinah. Sekaligus untuk mengetahui riilnya keadaan di Madinah. Mushab berhasil melaksanakan tugasnya. Dari situ Islam bisa berkembang luas di Madinah, Nabi juga mendapatkan informasi keadaan riil dan perkembangan Madinah dari Mushab. Kedua, dijelaskan oleh Shihab, bahwa pada masa awal di Madinah, Nabi memerintahkan untuk

Samson Rahman (Jakarta: Akbarmedia, 2012), 582583. 
menghitung orang-orang yang telah mengucapkan kalimat syahadat (Islam) dari pendduk Madinah. Dari hasil perhitungan tersebut, diketahui bahwa jumlah umat Islam saat itu kurang lebih 1500 orang. ${ }^{43}$ Perhitungan atau sensus tersebut tidak lain adalah pemetaan jumlah SDM yang berpotensi menjadi kekuatan umat Islam. Tentu saja metodologi pemetaan lingkungan yang dilakukan Nabi tidak hanya dua hal tersebut. Sangat dimungkinkan Nabi melakukan observasi langsung, mengamati keadaan SDMnya, dialog dengan para tokoh-tokoh di Madinah, baik dari Suku Aus maupun Khazraj, juga kepada orang-orang Yahudi, sehingga dari situ didapatkan gambaran situasi lingkungan dakwah yang dihadapinya.

Dari hasil pemetaan lingkungan yang dilakukan Nabi, tentunya ada hasil pemetaan dan analisisnya. Data dari para sejarawan memang tidak menunjukkan secara langsung hasil pemetaan dan analisis lingkungan yang dilakukan oleh Nabi. Namun terdapat sejumlah data yang menggambarkan bagaimana situasi sosial Madinah yang dihadapi Nabi pada masa tersebut, yang mana situasi tersebut mestinya juga telah dibaca oleh $\mathrm{Nabi}$ Muhammad. Situasi-situasi sosial itulah yang menjadi lingkungan strategis dakwah Nabi pada masa awal di Madinah. Dalam pemetaan lingkungan terdapat dua variabel besar, yaitu keadaan internal dan keadaan eksternal organisasi. Pemetaan lingkungan internal organisasi dakwah terkait keadaan SDM, produk yang didakwahkan, metode dan media yang dimiliki, serta sistem dan budaya organisasi. Pemetaan eksternal

\footnotetext{
${ }^{43}$ Shihab, Membaca Sirah., 517.

${ }^{44}$ Karen Armstrong, Muhammad Biografi Sang Nabi, diterjemahkan oleh Joko Sudaryanto (Yogyakarta:
}

terkait keadaan pasar, kompetitor, serta keadaan sosial politik ekonomi yang berpengaruh. Telah dijelaskan sebelumnya, bahwa Nabi memerintahkan melakukan perhitungan jumlah SDM orang Islam, yang diketahui jumlahnya sekitar 1500 orang. Nabi tidak hanya memetakan SDMnya secara kuantitatif, tetapi juga memetakan kualitas SDM yang dimiliki. Hal tersebut dapat diindikasikan dari adanya pembagian tugas yang menyesuaikan kapasitas SDM dan kebutuhan organisasi. Kualitas SDM di antaranya diukur dari idealisme (keimanan), loyalitas pada organisasi, kepribadian dan kompetensi yang dimiliki. Kaum Muhajirin, dapat dikategorikan sebagai SDM yang secara idealisme dan loyalitas telah teruji. Sementara orang Madinah yang menyatakan Keislamannya, idealisme dan loyalitasnya bervariasi. Terdapat dari mereka yang kualitas dan loyalitas tidak kalah dengan kaum Muhajirin, dan terbukti di kemudian hari memenuhi janjinya untuk membela Nabi dan Islam. Namun juga terdapat orang-orang yang lemah imannya dan ada penyakit dalam hatinya. Mereka inilah yang dalam sejarah selanjutnya disebut sebagai orang-orang munafik. Secara lisan menyatakan Islam, namun mereka memiliki maksud-maksud untuk menghancurkan organisasi dakwah Nabi di Madinah. Tidak diketahui secara pasti jumlahnya, namun jika mengacu pada peristiwa yang terjadi sesudah masa-masa awal di Madinah, yaitu pada Perang Uhud, terdapat sekitar 300 orang yang menarik pasukan dari perang dibawah pimpinan Abdullah bin Ubay, yang dipandang sebagai tokoh kaum munafik. ${ }^{44}$ Secara kepribadian dan kompetensi SDM yang dimiliki Nabi juga

Penerbit Jendela, 2004), 329; W. Montgomery Watt, Muhammad Sang Negarawan, diterjemahkan $A$. Asnawi, (Yogyakarta: Mitra Buku, 2016), 205-206. 
beragam. Ada yang memiliki talenta dalam pemecahan masalah dan kepemimpinan sosial, seperti Abu Bakar dan Umar bin Khattab, yang kemudian dijadikan sebagai pendamping (wazir) Nabi dalam pemecahan masalah organisasi dakwah dan keumatan. Ada yang memiliki kompetensi dalam komunikasi sehingga lebih banyak ditugaskan untuk pengembangan dakwah seperti Mushab bin Umair, Abu Ubaidah, Muadz bin Jabbal, dan sebagainya. Ada yang memiliki mentalitas dan kompetensi dalam teknis peperangan dan kekuatan fisik, seperti Hamzah bin Abdul Muthalib, Zubair bin Awwam, Saad bin Abi Waqash, Abdullah bin Jahsy, dan sebagainya. Ada pula yang memiliki kompetensi dalam bisnis, seperti Usman bin Affan dan Abdurrahman bin Auf, sehingga lebih banyak diarahkan untuk pembangunan dan pengembangan pasar di Madinah.

Produk dakwah yang ditawarkan oleh Nabi, secara substansi adalah ajaran tauhid. Riilnya dalam bentuk wahyu Alquran yang didapatkan Nabi Muhammad, yang pada masa tersebut tidak hanya turun terkait pembelajaran nilai-nilai tauhid, tetapi juga memberikan pemecahan-pemecahan masalah praktis terkait dinamika dakwah dan sosial yang dihadapi Nabi dan umat. Sehingga teks-teks wahyu yang turun sangat terikat dengan konteks yang melingkupinya. Metode dan media dakwah disampaikan secara langsung (lisan), baik melalui Nabi atau kemudian diteruskan oleh sahabat Nabi. Sebagai kelompok atau organisasi baru di Madinah, secara sistem dan perangkat-peragkat yang ada belum mapan. Nabi dihadapkan pada berbagai persoalan riil agar tujuan dakwahnya bisa tercapai. Persoalan-persoalan tersebut di antaranya terkait keberadaan tempat untuk konsolidasi organisasinya. Nabi Muhammad sendiri secara personal juga membutuhkan tempat tinggal. Keadaan kaum Muhajirin yang telah rela meninggalkan tanah kelahirannya, meninggalkan seluruh harta bendanya, padahal di Madinah mereka juga membutuhkan makan, perlu bekerja atau berdagang agar mendapat penghasilan. Sementara Madinah bukanlah kota perdagangan seperti Makkah. Beberapa sahabat sempat mengalami sakit, yang barangkali diakibatkan karena tidak cocok lingkungannya atau masih proses adaptasi. Keadaan internal semacam itulah yang dihadapi organisasi dakwah Nabi pada masa awal di Madinah.

Lingkungan eksternal yang dihadapi Nabi di Madinah adalah sebuah lingkungan baru yang berbeda dengan pasar dakwah sebelumnya di Makkah. Sebagaimana dijelaskan di atas, secara sosial politik dan keagamaan, wilayah Madinah lebih heterogen dari pada Makkah. Selain komunitas muslim, terdapat orang-orang Yahudi, sebagian kecil kaum Nasrani, dan orang-orang yang menyembah berhala. Komunitas muslim baru di Madinah itulah yang menjadi pasar utama dakwah yang perlu untuk terus dibina, dipertahankan, dan ditingkatkan kualitasnya, sehingga kelak perannya tidak hanya sebagai mitra dakwah tetapi juga subjek dakwah. Orang-orang yang belum menerima dakwah Islam, termasuk orang Yahudi dan Nasrani, juga dapat menjadi pasar dakwah Nabi di Madinah. Pasar dakwah tersebut adalah jenis baru, mengingat sebelumnya Nabi tidak mendakwahkan Islam kepada orang Yahudi di Makkah. Terlebih terdapat beberapa hal yang berpotensi untuk menjadikan orang Yahudi menerima dakwah Islam, seperti informasi dari kitab 
sucinya akan kedatangan Nabi akhir zaman, serta ajarannya yang juga menekankan pada monotheisme. Dalam sejarah diketahui bahwa Nabi memang pada awalnya berupaya mengajak orang-orang Yahudi agar menerima dakwah Islam. ${ }^{45}$ Aspek kompetitor dalam dakwah Nabi, pertama adalah orang-orang kafir Quraisy Makkah, khususnya para pemukanya. Sejak semula mereka telah menolak keras dakwah Islam. Hijrahnya sebagian penduduk Makkah yang muslim juga meninggalkan bekas keretakan di masyarakat Quraisy, sehingga mereka masih menyimpan kedengkian terhadap Nabi Muhammad, terlebih upaya mereka untuk membunuh Nabi sesaat sebelum hijrah menuai kegagalan. Kedua, orangorang Yahudi. Semula mereka adalah pasar dakwah. Namun dalam perkembangan, mereka menolak seruan Nabi, bahkan mengolok-oloknya. Tidak jarang mereka berupaya untuk melakukan seranganserangan intelektual kepada Nabi dan umat Islam untuk menjatuhkan maupun melemahkan dakwah Islam. Ketiga, orangorang munafik. Sebagaimana disebutkan sebelumnya, bahwa terdapat sejumlah orang-orang yang menyatakan Islam tapi ada penyakit dalam hatinya. Mereka benci dan dengki kepada Nabi Muhammad karena berbagai hal. Merekalah yang kelak berusaha menghancurkan organisasi Islam dari dalam. Pada masa awal Madinah, pergerakan orang-orang munafik memang belum terlihat, namun indikasi-indikasi ke arah sana mulai nampak. Alquran secara jelas menyinggung fenomena tersebut, guna memberikan kesadaran kepada Nabi dan umat Islam akan bahaya dari dalam akibat adanya orang-orang munafik. ${ }^{46}$

Dari uraian di atas dapat dibuat gambaran analisis kekuatan, kelemahan, peluang, dan ancaman sebagai hasil dari pemetaan lingkungan dakwah pada masa awal Madinah, yang diuraikan dalam tabel berikut:

Tabel 1 - Matriks Kekuatan, Kelemahan, Peluang dan Ancaman sebagai

Hasil Pemetaan Lingkungan Dakwah Masa Awal Madinah

\begin{tabular}{|c|c|}
\hline Kekuatan & Peluang \\
\hline $\begin{array}{l}\text { - Jumlah SDM yang besar; } \\
\text { - Terdiri atas Muhajirin dan Anshar; } \\
\text { - Kompetensi SDM bervariasi dan bertalenta } \\
\text { pada bidang tertentu; } \\
\text { - Produk dakwah bersumber dari wahyu Allah. }\end{array}$ & $\begin{array}{l}\text { - Tidak adanya otoritas politik yang tunggal di } \\
\text { Madinah; } \\
\text { - Secara keagamaan bervariasi (tidak tunggal), } \\
\text { masyarakatnya telah terbiasa hidup plural; } \\
\text { - Pasar dakwah di Madinah masih luas; } \\
\text { - Terdapat komunitas Yahudi yang cukup besar di } \\
\text { Madinah, yang secara ajaran lebih dekat dengan } \\
\text { Islam (dari pada kaum Pagan), sehingga potensial } \\
\text { untuk didakwahi; } \\
\text { - Posisi Madinah cukup strategis karena berada di } \\
\text { jalur perdagangan Makkah. }\end{array}$ \\
\hline Kelemahan & Ancaman \\
\hline $\begin{array}{l}\text { - Kaum Muhajirin tidak memiliki tempat tinggal } \\
\text { dan sumber penghidupan layak; } \\
\text { - Beberapa SDM mengalami masalah (sakit, } \\
\text { tidak betah); }\end{array}$ & $\begin{array}{l}\text { - Pihak Quraisy Makkah selalu mengancam dan } \\
\text { menginginkan kehancuran Nabi Muhammad; } \\
\text { - Terdapat orang-orang Yahudi Madinah yang tidak } \\
\text { siap/menolak dakwah Nabi Muhammad dan }\end{array}$ \\
\hline
\end{tabular}

${ }^{45}$ Ibnu Ishak - Ibnu Hisyam, Sirah Nabawiyah.

${ }^{46}$ Armstrong, Muhammad Biografi., 266. 
- Organisasi dakwah Nabi merupakan komunitas baru di Madinah;

- Organisasi dakwah Nabi belum memiliki tempat sebagai pusat kegiatan;

- Sistem-sistem di organisasi masih belum mapan (mulai merintis);

- Adanya SDM-SDM yang masih lemah imannya dan loyalitasnya. sering melakukan serangan-serangan pemikiran terhadap ajaran Islam;

- Terdapat orang-orang munafik, yang secara perlahan menggerogoti dan menginginkan kehancuran organisasi dakwah Nabi.
Dari penggambaran analisis keadaan lingkungan di atas, dapat diketahui bahwa secara internal posisi organisasi dakwah Nabi belumlah mapan pada masa awal di Madinah. Ada banyak masalah internal yang mendesak untuk diselesaikan, seperti terkait keadaan Kaum Muhajirin yang tidak memiliki sumber daya ekonomi untuk hidup di Madinah, belum lagi masalah adaptasi dengan lingkungan baru. Sementara tidak semua SDM memiliki kualitas keimanan dan loyalitas yang tinggi. Beberapa masih baru, dan lemah, sehingga mudah tersulut dan terprovokasi dari fitnah dan opini negatif yang dikembangkan oleh kompetitor dakwah. Secara eksternal, terdapat sejumlah peluang yang apabila itu dioptimalkan akan membuat posisi organisasi dakwah Nabi semakin kuat di Madinah. Namun juga ancaman dari kompetitor dakwah, yaitu dari orang kafir Quraisy Makkah, Kaum Yahudi, dan orang munafik, juga membayangi. Meskipun pada masa-masa awal di Madinah seranganserangan kompetitor belum seberapa agresif. Khusus, keberadaan orang Yahudi di Madinah memang menghasilkan peluang untuk direkrut dan riilnya Nabi juga berupaya melakukan rekrutmen tersebut. Namun mereka juga menjadi ancaman karena pemuka-pemukanya yang kemudian tidak hanya menolak dakwah Nabi tetapi juga berupaya menjatuhkan Nabi dan organisasi dakwah Islam kala itu. Dengan keadaan internal dan eksternal yang demikian, maka secara posisi strategis organisasi dakwah Nabi pada masa awal di Madinah, secara umum adalah posisi konsolidasi organisasi, namun juga terdapat potensi ke arah perluasan organisasi. Konsolidasi organisasi diperlukan mengingat terdapat sejumlah kelemahan internal yang harus segera diselesaikan, serta potensi-potensi ancaman yang harus disiapkan antisipasinya. Arah perluasan organisasi karena terdapat sejumlah peluang yang bisa dioptimalkan dengan kekuatan yang ada untuk semakin mengukuhkan keunggulan organisasi dakwah Nabi di Madinah. Dalam analisis SWOT maka pilihan strateginya adalah strategi WO (weakness-opportunity), yaitu memperbaiki kelemahan dengan mengambil keuntungan dari peluang eksternal, yang dikombinasikan dengan strategi SO (strength-opportunity) yaitu menggunakan kekuatan untuk mengoptimalkan peluang eksternal. Tentu saja untuk bisa menjalankan strategi $S O$, maka kelemahan internal harus diatasi terlebih dahulu.

\section{Keputusan-Keputusan Strategis Dakwah pada Masa Awal di Madinah dan Implementasinya}

Dari data sejarah diketahui terdapat beberapa kebijakan Nabi pada periode awal di Madinah. Kebijakan-kebijakan tersebut merupakan suatu keputusan strategis yang 
didasarkan pada pembacaan dan analisis dinamika lingkungan strategis dakwah pada masa tersebut. Sehingga setiap keputusan strategis Nabi dapat ditelusuri kaitannya dengan dinamika lingkungan organisasi dakwah dan dianalisis kesesuaiannya dengan arah atau posisi strategis organisasi pada masa tersebut. Keputusan-keputusan strategis tersebut antara lain, pertama, kebijakan pembangunan masjid. Langkah pertama yang dilakukan Nabi setelah tiba di Madinah adalah segera membangun masjid. Nampaknya rencana pembangunan masjid telah ada dalam benak Nabi sebelum tiba di Madinah, sehingga tidak mengherankan jika ketika Nabi sampai di Madinah, beliau mencari lahan yang bisa dibeli untuk pembangunan masjid. Barangkali Nabi juga sudah memperkirakan akan ada banyak tawaran dari penduduk muslim Madinah untuk tinggal di rumahnya atau menggunakan lahannya untuk masjid. Guna menghindari keributan akan hal tersebut, dengan taktis Nabi membiarkan ontanya berjalan sampai berhenti pada tempat tertentu yang kemudian dijadikan lahan pembangunan masjid. Sebagai sebuah komunitas baru di wilayah Madinah yang heterogen, Nabi menyadari akan kebutuhan suatu tempat yang berfungsi seperti sekretariat bagi organisasi dakwahnya. Di tempat itulah konsolidasi organisasi dilakukan, menjadi pusat kegiatan dakwah dan pendalaman ajaran Islam, beribadah, sekaligus untuk menampung umat Islam yang tidak memiliki tempat tinggal di Madinah. Maka dibangunlah masjid, yang kemudian diberi nama Masjid Nabawi. Secara personal, Nabi juga membutuhkan tempat tinggal. Agar lebih efektif dan efisien, maka dibangun pula rumah (bilik) yang menempel dengan dinding masjid sebagai tempat tinggal Nabi. Kebijakan pembangunan masjid, juga berimplikasi pada keputusan posisi kiblat yang ketika itu diputuskan menghadap ke arah Baitul Maqdis, sebagaimana kiblatnya orang Yahudi. Hal tersebut dilakukan salah satunya adalah untuk menarik minat orang yahudi terhadap Islam. Selain itu juga terkait kebijakan teknis pemanggilan waktu berkumpul untuk salat di masjid. Nabi menginginkan suatu cara baru yang berbeda dengan Yahudi, Nasrani, maupun agama lainnya, sebagai penanda identitas kelompok muslim. Akhirnya diputuskan digunakan cara pemanggilan dengan suara, yang kemudian disebut azan. Sahabat Bilal bin Rabbah ditunjuk Nabi untuk mengeksekusi kebijakan azan.

Kedua, kebijakan mempersaudarakan Muhajirin dan Anshar. Dengan hijrahnya Nabi dan umat Islam Makkah ke Madinah, maka organisasi dakwah Nabi ditopang oleh dua kelompok SDM yaitu kaum Muhajirin (Makkah) dan kaum Anshar (Madinah). Kedua kelompok ini tentu memiliki kultur dan karakter yang berbeda, idealisme dan loyalitasnya juga beragam. Perbedaanperbedaan tersebut perlu dikelola dan disatukan dalam naungan ide yang sama. Nantinya mereka harus bisa bekerjasama untuk pengembangan organisasi dakwah, kekompakkan dan persatuan dua kelompok tersebut sangat diperlukan. Sementara secara aktual, hijrahnya umat Islam berimplikasi pada adanya masalah akan kebutuhan pokok hidup mereka, sehingga Kaum Muhajirin dalam posisi lemah di Madinah. Situasi tersebut tentu mendesak untuk dipecahkan. Berdasarkan analisis situasi-situasi tersebut diambillah kebijakan mempersaudarakan kaum Anshar dan Muhajirin. Di samping persoalan ekonomi, persaudaraan tersebut juga untuk 
memecahkan persoalan sosial kaum Muhajirin, karena mereka adalah orangorang baru di Madinah, yang datang sendirian atau keluarga kecil, sehingga kesepian dapat menghantui mereka. Bisa jadi cuaca pun merupakan ketidaknyamanan tersendiri karena cuaca Madinah sangat dingin di musim dingin dan sangat panas di musim panas. ${ }^{47}$ Nabi sendiri yang secara langsung mengumumkan kebijakan persaudaraan tersebut. Barangkali pengumuman tersebut dilaksanakan, setelah sebelumnya Nabi memerintahkan untuk melakukan pendataan (sensus) umat Islam di Madinah. Semua orang Muhajirin memiliki saudara Anshar, kecuali Nabi sendiri dan keluarganya. ${ }^{48}$ Diriwayatkan bahwa ketika itu Nabi mempersaudarakan puluhan orang, 80 atau 90 orang, misalnya mempersaudarakan Abu Bakar dengan Kharijah bin Zaid, Umar bin Khathab dengan Usman bin Malik, Usman bin Affan dengan Aus bin Tsabit, Thalhah bin Abdillah dengan Kaab bin Malik, dan sebagainya. ${ }^{49}$

Ketiga, kebijakan perjanjian untuk menggalang kerukunan/persatuan di Madinah. Hasil dari kebijakan tersebut kemudian lebih dikenal sebagai Piagam Madinah. Telah disinggung sebelumnya bahwa masyarakat Madinah adalah masyarakat yang heterogen, terdapat banyak kelompok keagamaan yang tinggal di Madinah dan sekitarnya. Ketiadaan otoritas politik tunggal di Madinah merupakan peluang bagi Nabi untuk mencapai posisi tersebut. Posisi Nabi di Madinah relatif diuntungkan karena sebagai kelompok baru, Nabi tidak terlibat dengan konflik masa lalu yang pernah terjadi antar penduduk Madinah. Semua kelompok di Madinah, termasuk Yahudi, juga berkepentingan untuk bisa mendapatkan dukungan dari Nabi Muhammad. Situasisituasi inilah yang bisa jadi telah dibaca oleh Nabi. Nabi sendiri memiliki kepentingan untuk mensukseskan misi dakwahnya, tidak hanya di Madinah, tapi sampai ke penjuru Arab. Sisi lain, Nabi juga menyadari bahwa kelompoknya telah meninggalkan luka kepada para pemuka kafir Quraisy Makkah karena hijrah, dan konflik yang untuk sementara waktu terhenti, sehingga potensi ancaman dari Makkah cukup besar. Berbagai analisis situasi itulah yang menjadi pijakan Nabi, untuk mengoptimalkan kekuatan dan keuntungan posisi strategis yang dimilikinya guna menggalang kerukunan di Madinah. Kebijakan tersebut dieksekusi dengan membuat perjanjian tertulis dengan berbagai kelomok-kelompok suku baik muslim maupun nonmuslim yang ada di Madinah, dalam dokumen tertulis Piagam Madinah. Diriwayatkan pada dokumen perjanjian tersebut orang Yahudi Bani Quraizhah, Bani al-Nadhir, dan Bani Qainuqa (tiga kelompok besar Yahudi Madinah) tidak ikut menandatangani, tetapi tidak lama kemudian mereka juga mengadakan perjanjian serupa dengan Nabi. ${ }^{50}$ Dokumen itu telah menetapkan soa kebebasan beragama, kebebasan menyatakan pendapat, perlindungan hartabenda, dan larangan orang melakukan kejahatan, termasuk dalam upaya bersama untuk mempertahankan keamanan kota Madinah dari serangan kelompok luar.

\footnotetext{
${ }^{49}$ Shihab, Membaca Sirah., 514.

${ }^{50}$ Haekal, Sejarah Hidup., 333.
} 
Keempat, kebijakan membangun pasar. Nabi menyadari sepenuhnya bahwa orangorangnya perlu memiliki perekonomian yang tangguh. Keberhasilan dakwahnya perlu ditopang dengan keberhasilan ekonomi masyarakatnya. SDMnya kaum Muhajirin yang berasal dari Makkah merupakan kaum pedagang, sehingga ada modal untuk membangun pasar, sekaligus sebagai pemecahan untuk penguatan ekonomi umat Islam khususnya kaum Muhajirin. Sebelumnya pasar di Madinah dikuasai oleh orang-orang Yahudi, yang secara tidak langsung membuat mereka mengendalikan perekonomian di Madinah. Terlebih mereka menerapkan riba. Oleh karenanya Nabi memerintahkan untuk membangun pasar. Dalam implementasinya Nabi terlibat secara langsung dalam pemilihan lokasi pasar, yaitu di sebelah barat masjid yang beliau bangun. Beliau menandainya dengan menggaris batasbatasnya dengan kaki beliau. Beliau menentukan lokasi dalam pasar untuk menjajakan komoditi yang diperjualbelikan; ternak, bahan makanan, dan sebagainya. Dengan lokasi yang dekat masjid, memungkinkan bagi Nabi untuk sesekali melakukan pengawasan terhadap aktivitas pasar di masyarakatnya. ${ }^{51}$

Kelima, kebijakan sariyah dan ghazwah, kegiatan pengintaian dan penyergapan/penjarahan kafilah dagang Quraisy. Telah dijelaskan bahwa Madinah memiliki posisi strategis karena berada di jalur perdagangan Makkah dan Syiria. Setiap tahunnya kafilah dagang berlalu-lalang dari Mekah ke Syiria atau sebaliknya. Nilai komoditas barang dagangan yang dibawa bisa sangat besar. Quraisy Makkah adalah

${ }^{51}$ Shihab, Membaca Sirah., 520-521. ancaman bagi dakwah Nabi. Mereka memiliki dendam dan keinginan untuk menghancurkan Islam. Sementara secara sosiologis, penjarahan atau gazwah merupakan kebiasaan bangsa Arab dan sebuah cara yang lazim pada masa itu untuk memenuhi kebutuhan hidup pada masa sulit. ${ }^{52}$ Secara internal, keadaan umat Islam, khususnya Kaum Muhajirin saat itu tengah mengalami masa sulit secara ekonomi. Sekalipun telah diambil kebijakan persaudaraan Muhajirin dan Anshar, serta pembangunan pasar, namun hal tersebut belum secara sepenuhnya melepaskan umat Islam dari situasi sulit tersebut. Berpijak dari situasi internal dan eksternal, serta guna pemecahan masalah aktual, maka Nabi membuat keputusan strategis untuk melakukan pengintaian dan penyergapan terhadap kafilah dagang Quraisy. Sasaran mereka sangat spesifik hanya kepada Quraisy. Sehingga tujuannya tidak semata ekonomi, tetapi juga untuk memberikan pesan kepada pemuka kafir Quraisy Makkah terkait eksistensi organisasi dakwah Nabi serta bargaining power, agar Quraisy Makkah juga tidak sembarangan dan mau menghormati dakwah Islam. Disamping itu ketika umat Islam Makkah hijrah, kaum musyrik Makkah merampas harta mereka. Dalam implementasinya, komando kegiatan pengintaian dan penyergapan dikepalai langsung oleh Nabi. Nabi membentuk pasukan-pasukan yang dipimpin oleh beberapa sahabat untuk melakukan pengintaian dan penyergapan kepada kafilah dagang Quraisy. Sebagai contoh pada bulan Ramadhan tahun pertama hijrah Nabi menugaskan Hamzah bin Abdul Muththalib bersama 30 orang dari kaum Muhajirin untuk menghadang kafilah

\footnotetext{
${ }^{52}$ Armstrong, Muhammad., 291-292.
} 
yang beranggotakan 300 orang yang dipimpin oleh Abu Jahal dalam perjalanan pulang mereka ke Makkah dari Syam, yang hamper saja menyebabkan peperangan. Berikutnya, Nabi juga menegaskan sahabat 'Ubaidah bin al-Harits bin al-Muththalib untuk memimpin 60 orang kaum Muhajir, Saad bin Abi Waqqash dalam satu rombongan sejumlah 20 orang. Dalam beberapa kegiatan ghazwah, Nabi sendiri yang turun untuk memimpin pasukan. ${ }^{53}$ Salah satu kegiatan ghazwah yang dipimpin Nabi pada tahun kedua Hijriah adalah menyergap kafilah dagang Quraisy dari Syam yang dipimpin oleh Abu Sofyan, salah seorang pemuka kafir Quraisy. Nabi berangkat bersama sekitar 300 orang, namun kafilah dagang Abu Sofyan berhasil menghindari sergapan pasukan Muslim dan mengirimkan kabar ke Makkah untuk membantunya. Para pemuka Quraisy menghimpun pasukan sejumlah sekitar seribu orang. Perang kedua pasukan tidak dapat dihindarkan. Dengan penguasaan medan dan taktik perang yang jitu, Nabi berhasil mengkoordinir pasukannya dengan baik dan memenangkan pertempuran tersebut. Kemenangan yang kemudian mengokohkan posisi organisasi Nabi di Madinah.

Keenam, kebijakan terhadap orang-orang Yahudi Madinah. Yahudi merupakan salah satu komunitas yang walaupun minoritas tetapi mempunyai peranan yang signifikan di Madinah, khsusunya dalam penguasaan perekonomian pasar. Secara ajaran juga lebih dekat dengan Islam, sama-sama mengakui satu Tuhan. Nabi melihat bagaimana mereka menyambut baik

\footnotetext{
53 Shihab, Membaca Sirah., 524-525, 534.

${ }^{54}$ Haekal, Sejarah Hidup., 328.
}

kedatangannya meski dengan maksud agar beliau mau dibujuk bergabung dengan mereka. Beliau membalas penghormatan mereka itu dengan penghormatan yang sama dan menjalin silaturahim dengan mereka. Nabi berbicara dengan para pemuka mereka, lalu mengikat mereka dengan tali persahabatan. Bahkan, pada waktu kaum Yahudi berpuasa, Nabi ikut berpuasa. Begitu pula, kiblat salat kaum muslim pada waktu itu masih ke arah Baitul Maqdis yang merupakan pusat perhatian kaum Yahudi dan tempat berkumpul Bani Israil. Dengan begitu, persahabatan Nabi dengan kaum Yahudi semakin hari semakin erat dan dekat. ${ }^{54} \mathrm{Hal}$ tersebut dilakukan Nabi dalam rangka untuk menarik kaum Yahudi agar bersedia menerima dakwah Islam. Nabi melihat ada peluang dakwah pada kalangan Yahudi. Namun upaya tersebut tidak banyak membuahkan hasil. Hanya sedikit saja tokoh Yahudi yang bersedia masuk Islam, salah satunya adalah seorang rabbi yang cerdik dan pandai, yaitu Abdullah ibn Salam. Sikap asli kaum Yahudi mulai terlihat. Mereka membuat intrik melalui para rahib yang pura-pura Islam. Mereka bergaul dengan kaum muslim sambil pura-pura bertakwa, lalu sesekali menunjukkan kesangsian dan keraguan. Mereka memajukan berbagai pertanyaan kepada Rasulullah dengan tujuan untuk mengguncangkan keyakinan umat Islam kepada beliau dan ajaran kebenaran yang dibawanya. Lalu orang Aus dan Khazraj yang juga berpura-pura masuk Islam bergabung dengan orang Yahudi mengajukan berbagai pertanyaan dan memicu perselisihan di antara kaum muslim. ${ }^{55}$ Adanya perubahan situasi sikap orang Yahudi, membuat Nabi

55 Ibid., 344. 
mengevaluasi kembali strateginya. Jika semula Nabi memiliki strategi untuk mencoba merekrut orang Yahudi, melihatnya sebagai pasar dakwah, maka dengan sikap-sikap pertentangan dan penyerangan intelektual kepada Nabi, maka mereka tidak lagi diposisikan sebagai pasar melainkan kompetitor dakwah.

Selain keenam kebijakan di atas, terdapat keputusan yang terkait pribadi Nabi Muhammad dan keluarganya, yaitu pernikahan Nabi dengan Aisyah binti Abu Bakar, dan pernikahan Nabi dengan Hafsah binti Umar bin Khattab. Nabi juga menikahkan putrinya, Fatimah, dengan sahabat dan sepupunya, Ali bin Abi Thalib. Dalam perspektif manajemen strategis keputusan pernikahan tersebut lebih dari sekedar masalah pribadi dan keluarga Nabi. Secara sosiokultural, pernikahan di Arab menjadi salah satu jalan untuk memperkuat hubungan antar sahabat, kabilah, maupun suku. Dengan pernikahan maka hubungan keduanya lebih erat lagi. Alasan-alasan itulah yang menjadi pendorong utama Nabi untuk menikah dengan putri kedua sahabatnya, yang sekaligus merupakan penasehatnya dalam pemecahan masalah di organisasi. Semula Nabi hanya menikahi putri Abu Bakar, namun ketika suami dari Hafsah binti Umar bin Khattab meninggal, dan Umar menawarkan putrinya untuk dinikahi, Nabi bersedia. Demikian pula pernikahan putri Nabi dengan Ali bin Abi Thalib. Maka kebijakan pernikahan ini sekaligus menjadi bagian dari langkah konsolidasi untuk penguatan internal organisasi dakwah Nabi.

Dari gambaran serangkaian keputusan strategis dan implementasinya di atas terlihat bagaimana setiap kebijakan selalu terkait dengan dinamika lingkungan yang dihadapi Nabi. Hal tersebut menandakan bahwa proses perumusan strategi yang dilakukan senantiasa berlandaskan pada pemetaan dan analisis lingkungan organisasi dakwah. Secara umum hasil analisis lingkungan dakwah pada masa awal di Madinah menyebutkan bahwa arah posisi strategis organisasi dakwah Nabi adalah konsolidasi internal, dan terdapat potensi perluasan program organisasi. Maka strategi konsolidasi internal menjadi kunci bagi keberlanjutan organisasi dakwah serta pencapaian keunggulan kompetitif internal. Dalam pencocokan analisis SWOT di atas diketahui bahwa strategi utama yang dapat dipilih adalah strategi $W O$, yang kemudian dapat dikombinasikan dengan strategi $S O$. Kebijakan Nabi untuk membuat perjanjian di internal kelompoknya dengan mempersaudarakan kaum Anshar dan Muhajirin, serta perjanjian dengan kelompok-kelompok eksternal di lingkungan Madinah, termasuk kepada Yahudi, adalah kebijakan-kebijakan untuk mengatasi masalah kelemahan internal organisasi dakwah Nabi dengan memanfaatkan peluang eksternal organisasi dakwah. Demikian pula dengan kebijakan pembangunan masjid, pembangunan pasar, dan kegiatan sariyyah dan ghazwah, juga memiliki dimensi untuk penguatan internal dengan optimalisasi peluang eksternal. Dengan kekuatan internal yang ada, Nabi juga berupaya meraih peluang-peluang eksternal yang dimilikinya, seperti kebijakan untuk pengembangan dakwah kepada Kaum Yahudi, kegiatan sariyyah dan ghazwah juga memiliki dimensi penggunaan kekuatan internal untuk mengoptimalkan peluang posisi strategis Madinah dalam jalur perdagangan Makkah - Syiria. Berikut gambaran uraian dimensi SWOT sebagai 
dasar perumusan strategi kebijakan-

kebijakan Nabi pada masa awal di Madinah:

Tabel 2 - Gambaran/Proyeksi Pencocokan Analisis SWOT sebagai Dasar Permusuan Strategi

\begin{tabular}{|c|c|c|}
\hline No & Keputusan Strategi & $\begin{array}{c}\text { Pencocokan Analisis SWOT sebagai Dasar Perumusan } \\
\text { Strategi }\end{array}$ \\
\hline 1 & Pembangunan Masjid & $\begin{array}{l}\text { Masalah ketiadaan tempat sebagai pusat kegiatan } \\
\text { organisasi dakwah Nabi, sehingga perlu membangun } \\
\text { masjid dengan memanfaatkan/membeli lahan kosong } \\
\text { penduduk Madinah (WO). }\end{array}$ \\
\hline 2 & $\begin{array}{l}\text { Mempersaudarakan } \\
\text { Muhajirin dan Anshar }\end{array}$ & $\begin{array}{l}\text { Masalah persatuan internal dan sosial ekonomi kaum } \\
\text { Muhajirin adalah kelemahan yang harus segera diatasi, } \\
\text { untuk menghindari ancaman kegagalan penyesuaian di } \\
\text { tempat baru (WT). }\end{array}$ \\
\hline 3 & $\begin{array}{l}\text { Perjanjian untuk Menggalang } \\
\text { Kerukunan di Madinah (Piagam } \\
\text { Madinah) }\end{array}$ & $\begin{array}{l}\text { Orgaisasi dakwah Nabi sebagai kelompok baru di } \\
\text { Madinah perlu mengukuhkan eksistensinya sementara di } \\
\text { Madinah sosiokulturnya beragam dan tidak ada otoritas } \\
\text { politik tunggal (WO). }\end{array}$ \\
\hline 4 & Pembangunan Pasar & $\begin{array}{l}\text { Masalah perekonomian umat, perlu membangun pasar } \\
\text { dengan memanfaatkan lahan di sekitar masjid, sementara } \\
\text { pasar di Madinah jumlahnya juga terbatas (WO). }\end{array}$ \\
\hline 5 & Dakwah kepada Yahudi & $\begin{array}{l}\text { Nabi memiliki produk dakwah (wahyu) yang terdapat } \\
\text { kesamaan dengan ajaran Yahudi seperti kepercayaan } \\
\text { terhadap satu Tuhan, dan lain-lain. Di kalangan Yahudi } \\
\text { juga terdapat kepercayaan akan datangnya Nabi akhir } \\
\text { zaman (SO). }\end{array}$ \\
\hline 6 & $\begin{array}{l}\text { Pengintaian dan Penyergapan } \\
\text { (sariyyah dan ghazwah) Kafilah } \\
\text { Dagang Quraisy }\end{array}$ & $\begin{array}{l}\text { Masalah eksistensi organisasi dakwah Nabi, ancaman dari } \\
\text { Quraisy, dan kebutuhan ekonomi, terdapat peluang letak } \\
\text { Madinah yang strategis dalam jalur perdagangan Quraisy, } \\
\text { kegiatan sariyyah dan ghazwah sudah menjadi kultur } \\
\text { Arab. Secara internal memiliki jumlah SDM dan kualitas } \\
\text { SDM yang memadai (WO-SO-ST). }\end{array}$ \\
\hline 7 & $\begin{array}{l}\text { Pernikahan Nabi dengan putri } \\
\text { sahabatnya }\end{array}$ & $\begin{array}{l}\text { Perlunya penguatan internal SDM organisasi, secara } \\
\text { kultural pernikahan adalah sarana untuk penguatan antar } \\
\text { sahabat atau kelompok (WO). }\end{array}$ \\
\hline
\end{tabular}

\section{Evaluasi Strategi Dakwah pada Masa}

\section{Awal Madinah}

Keberhasilan satu strategi yang dieksekusi dengan baik di lapangan berpengaruh terhadap implementasi strategi lainnya. Dinamika tersebut diamati dan dipantau oleh Nabi. Demikian pula keadaaan perkembangan situasi lingkungan dakwah di internal dan eksternal. Untuk itu dilakukan pengendalian dan evaluasi strategi dakwah.
Salah satu kasus yang dapat menjadi bukti adanya pengendalian dan evaluasi strategi pada masa awal di Madinah adalah kebijakan pemindahan arah kiblat dari Baitul Maqdis ke Kakbah di Makkah. Kebijakan ini berkaitan dengan evaluasi terhadap pelaksanaan kebijakan dakwah pada kaum Yahudi dan perubahan sikap (mulai menunjukkan sikap yang 
sebenarnya) Yahudi yang mulai menyerang dakwah Islam.

Keberhasilan eksekusi beberapa strategi dakwah membuat posisi kaum muslim di Madinah semakin kuat. Saat itulah orang Yahudi mulai memikirkan kembali posisi mereka di sisi Muhammad dan para sahabatnya. Seblumnya mereka telah menjalin perjanjian dengan Muhammad dengan tujuan untuk merangkulnya ke pihak mereka. Kaum Yahudi juga mulai mengkhawatirkan nasib mereka kelak jika lebih banyak lagi pengikut mereka yang memeluk Islam. Dari situ mulai tumbuh upaya kaum Yahudi untuk melemahkan dakwah Islam. Mereka memajukan berbagai pertanyaan kepada Rasulullah dengan tujuan untuk mengguncangkan keyakinan umat Islam kepada beliau dan ajaran kebenaran yang dibawanya. Mereka mulai merancang berbagai tipu daya dan gangguan agar bisa mengusir Muhammad keluar dari Madinah. Mereka mengatakan kepada Muhammad bahwa para rasul sebelum Muhammad, semuanya pergi ke Baitul Maqdis, karena memang di sanalah tempat tinggal para nabi. Apabila Muhammad benar-benar seorang rasul, seharusnya ia mengikuti para nabi terdahulu, yaitu menetap di Baitul Maqdis. Mereka bilang, kota Madinah ini hanyalah kota perantara dalam hijrahnya dari Makkah menuju Masjidil Aqsha. ${ }^{56}$ Tentu saja, Nabi dapat membaca tipu muslihat tersebut. Selain itu orang-orang Yahudi sering mengunggulkan ajarannya sebagai ajaran yang terdahulu, dan apa yang dibawa Muhammad tidak lebih sebagai turunannya saja. Di sisi lain, bagi orang-orang Muhajirin dan Anshar, Kakbah di Makkah lebih memiliki keterkaitan historis dengan sistem religius Arab dari pada Baitul Maqdis. Nabi Muhammad merasa sangat perlu untuk melepaskan diri dari keterkaitan dengan Yahudi. Maka setelah kurang lebih 17 bulan tinggal di Madinah, terdapat keputusan strategis untuk merubah kiblat umat Islam, yang dikukuhkan melalui wahyu Allah dalam surah Albaqarah (2):144. Kebijakan tersebut lahir dari perkembangan situasi untuk menjawab tantangan orang-orang Yahudi, bahwa muslim berbeda dengan Yahudi, secara identitas religius, ajarannya lebih murni karena mewarisi ajaran Ibrahim yang lurus. Ibrahim yang mendirikan kakbah bersama putranya, Ismail. Sejak saat itu, posisi Yahudi secara tegas bukan lagi sebagai pasar dakwah tetapi kompetitor dalam dakwah Nabi. Dan terbukti pada masa-masa selanjutnya, Kaum Yahudi melakukan berbagai tindakan untuk menghancurkan Nabi dan umat Islam.

Kasus pemindahan kiblat adalah salah satu contoh bagaimana proses pengendalian dan evaluasi dalam manajemen strategi dakwah Nabi pada masa awal Madinah dilakukan. Tentu saja keseluruhan strategi yang diputuskan dan dijalankan oleh Nabi, juga dievaluasi. Hanya saja tidak banyak data sejarah yang mengungkap bagaimana proses dan hasil evaluasi tersebut. Selain kasus di atas, pelaksanaan kebijakan pengintaian dan penyergapan kafilah dagang Quraisy juga terdapat indikasi adanya pengendalian dan evaluasi, khususnya dalam aspek implementasi. Dalam eksekusinya Nabi Muhammad membuat beberapa pasukan, ada yang dipimpin sahabatnya dan ada yang beliau pimpin secara langsung. Sahabat yang

56 Ibid., 349. 
memimpin juga bervariasi, yang jelas adalah mereka yang memiliki kapabilitas dalam tugas tersebut. Sebagai contoh seperti sahabat Saad bin Abi Waqash, sebelumnya dia menempati posisi sebagai pasukan dalam pasukan Ubadah bin Harist. Dalam penyergapan yang dilakukan, Saad berhasil dengan baik membantu pasukan muslim terhindarkan dari korban. Barangkali dari evaluasi kemampuan dan keberhasilan tersebut, pada ekspedisi penyergapan selanjutnya, Saad dipercaya oleh Nabi untuk menjadi pemimpin pasukan sariyyah dan gahzwah. ${ }^{57}$

\section{Kesimpulan}

Pemetaan dan analisis lingkungan dakwah pada masa awal Madinah menunjukkan bahwa organisasi dakwah Nabi menghadapi banyak kelemahan atau masalah-masalah internal yang menuntut segera diselesaikan. Mulai dari ketiadaan tempat, status sebagai pendatang atau kelompok baru, proses adaptasi, masalah ekonomi, dan sebagainya. Terdapat sejumlah kekuatan internal yang dimiliki seperti kuantitas dan kualitas SDM, serta produk dakwah. Terdapat pula peluang-peluang eksternal, seperti posisi Madinah yang strategis dalam jalur perdagangan, ketiadaan otoritas politik tunggal, masyarakatnya yang heterogen, dan sebagainya. Dalam aspek ancaman eksternal juga terdapat sekalipun belum agresif, di antaranya dari kafir Quraisy Makkah, para pemuka Yahudi yang menolak Islam, serta keberadaan orang-orang munafik. Dari pemetaan tersebut maka dapat diidentifikasi bahwa arah posisi strategis organisasi dakwah Nabi saat itu adalah konsolidasi internal, sebab banyak kelemahan internal yang harus segera dipecahkan, namun juga terdapat arah pengembangan program dengan tersedianya kekuatan internal untuk mengoptimalkan peluang eksternal. Sehingga secara umum dengan pendekatan SWOT maka pilihan-pilihan strateginya banyak mengarah pada strategi $W O$ yaitu menghilangkan kelemahan atau menguatkan internal organisasi dengan memanfaatkan peluang eksternal. Hampir sebagian besar keputusan-keputusan strategis diarahkan ke sana, seperti pembangunan masjid, pembangunan pasar, Piagam Madinah, pengintaian dan penyergapan kafilah dagang Quraisy, dan lainnya. Sebagian keputusan strategi mengarah pada strategi SO seperti upaya dakwah kepada Yahudi dan penyergapan kafilah dagang Quraisy. Pengendalian dan evaluasi strategi juga dilakukan, di antaranya diperlihatkan pada kasus pemindahan kiblat.

Walhasil secara keseluruhan dengan tools manajemen strategi yang tepat, organisasi dakwah Nabi Muhammad dapat melewati tahun pertama dan kedua di Madinah dengan baik. Misi dakwah di Madinah terlaksana, eksistensi organisasi dakwah Nabi diakui, bahkan semakin kukuh manakala mendapatkan keberhasilan dalam eksekusi beberapa kebijakan strategis. Keunggulan kompetitif dapat dicapai, di antaranya dari aspek SDM organisasi dakwah, produk yang didakwahkan, serta kepemimpinan organisasi dakwah. Dari uraian di atas terlihat bahwa dalam setiap pengambilan keputusan-keputusan strategisnya, pijakan pembacaan dan analisis lingkungan sangat dominan

${ }^{57}$ Shihab, Membaca Sirah., 527. 
dilakukan oleh Nabi Muhammad. Demikian pula dalam implementasi dan evaluasi strategi. Hal tersebut menunjukkan bahwa secara substansi dalam pengembangan organisasi dakwahnya Nabi Muhammad menggunakan perangkat keilmuan manajemen strategi.

Tulisan ini berangkat dari permasalahan minimnya organisasi dakwah pada hari ini yang dikelola dengan perangkat keilmuan manajemen strategi. Dengan mengkaji dakwah Nabi Muhammad yang terbukti menerapkan prinsip-prinsip manajemen strategi diharapkan dapat menjadi inspirasi dan pelajaran bagi aktivis organisasi dakwah. Sehingga jika Nabi Muhammad dalam dakwahnya sangat ketat dalam pembacaan dan analisis lingkungan dakwah, perumusan dan implementasi strategi dengan baik, serta pengendalian dan evaluasi strategi, maka para pelaku dakwah dewasa ini juga harus demikian, melakukan pembacaan dan analisis lingkungan dakwah, merumuskan dan implementasi strategi, serta pengendalian dan evaluasi strategi. Ilmu manajemen strategi adalah perangkat yang tepat untuk dapat melaksanakan itu semua. Oleh karenanya menjadi keharusan bagi organisasi dakwah hari ini untuk melaksanakan misi dakwah secara kompetitif menggunakan perangkat ilmu manajemen strategi.

\section{Bibliografi}

Affandy, Shofyan. Dakwah Strategik: Sebuah Ancangan Teoritis \& Filosofis. Surabaya: Avvatera, 2017.

Ajrin, Muhammad. "Manajemen Strategi dalam Mengelola Dakwah pada Pesantren Al-Husainy di Kota Bima." Skripsi, UIN Alaudin Makasar, 2017.

Al-Ghadban, Syaikh Munir Muhammad. Manhaj Haraki Strategi Pergerakan dan Perjuangan Politik Nabi Saw. Jilid 1. Diterjemahkan Aunur Rafiq Shalih Tamhid. Jakarta: Robbani Press, 1992.

Al-Mubarakfury, Syaikh Shafiyyurahman. Sirah Nabawiyah. Diterjemahkan Kathur Suhardi. Jakarta: Pustaka Al-Kautsar, 2012.

Al-Warisyi, Iskandar. Dakwah Illahiah. Surabaya: Penerbit Yayasan Al-Kahfi, 2009.

Antariksa, Walid Fajar. "Penerapan Manajemen Strategi dalam Dakwah Nabi Muhammad, saw.," Jurnal Manajemen Pendidikan Islam, Volume 2, nomor 1 (Juni 2017):28-37. DOI: http://dx.doi.org/10.188860/impi.v2i1.4357

Armstrong, Karen. Muhammad Biografi Sang Nabi. Diterjemahkan oleh Joko Sudaryanto. Yogyakarta: Penerbit Jendela, 2004.

Aswadi. Dakwah Progresif Perspektif Alquran. Sidoarjo: Dwiputra Pustaka Jaya, 2016.

Basit, Abdul. "Pemberdayaan Majelis Taklim dalam Perspektif Manajemen Dakwah," Jurnal Komunika, Vol.4 No.2 (Juni-Desember 2010): 251-268.

David, Fred R. Manajemen Strategis: Konsep, Edisi 12, Buku 1. Diterjemahkan Dono Sunardi, Jakarta: Salemba Empat, 2009.

Haekal, Muhammad Husein. Sejarah Hidup Muhammad. Cetakan Keempatpuluh Satu. Diterjemahkan Ali Audah. Jakarta: Litera AntarNusa, 2013. 
Harmoyo, Dwi. "Analisis Manajemen Strategis Koeprasi Jasa Keuangan Syariah Baitul Mal wat Tamwil Syariah Sejahtera Boyolali." Thesis, STAIN Surakarta, 2011.

Hutabarat, Jemsly \& Huseini, Martani. Strategi Pendekatan Komprehensif dan Terintegrasi "Strategic Excellence" dan "Operational Excellence" secara Simultan. Jakarta: Penerbit UI, 2011.

Ishaq, Ibnu - Hisyam, Ibnu. Sirah Nabawiyah. Diterjemahkan Samson Rahman. Jakarta: Akbarmedia, 2012.

Kadarsih, Ristiana \& Zamroni, Mohammad. "Urgensi Manajemen Strategis dalam Pengorganisasian Dakwah," Jurnal MD, Vol.I No.1, (Juli-Desember, 2008).

Moleong, Lexy J. Metodologi Penelitian Kualitatif, Cetakan ketigapuluhempat. Bandung: Rosda, 2015.

Munir, M. \& Ilaihi, Wahyu. Manajemen Dakwah. Jakarta: Kencana, 2006.

Muzayin, Arif. "Studi Manajemen Lembaga Pendidikan Dakwah di Masjid Agung Kota Blitar," Jurnal Kajian dan Pengembangan Manajemen Dakwah, Volume 04 Nomor 01 (Juni 2014):83-101.

Nawawi, Ismail. Metode Penelitian Kualitatif. Jakarta: Dwiputra Pustaka, 2012.

Pearce, John A. \& Robinson, Richard B. Manajemen Strategis: Formulasi, Implementasi, dan Pengendalian, Edisi 12 Buku 1. Diterjemahkan Nia Pramitasari. Jakarta: Salemba Empat, 2013.

Salahi, M.A. Muhammad sebgai Manusia dan Nabi. Diterjemahkan M. Sadat Ismail. Yogyakarta: Mitra Pustaka, 2010.

Shihab, M. Qurasih. Membaca Sirah Nabi Muhammad Saw. dalam Sorotan Alquran dan HadisHadis Shahih. Tangerang: Lentera Hati, 2012.

Sukardi. Metodologi Penelitian Pendidikan. Jakarta: Bumi Aksara, 2012.

Syukur, Asmuni. Dasar-Dasar Strategi Dakwah Islam. Surabaya: Al-Ikhlas, 1983.

Tresna, Yuana Ryan. Muhammad saw on The Art of War: Manajemen Strategi Peperangan Rasulullah saw. Bandung: Progressio, 2006.

Watt, W. Montgomery. Muhammad Sang Negarawan. Diterjemahkan A. Asnawi. Yogyakarta: Mitra Buku, 2016.

Wheelen, Thomas L. \& Hunger, J.D. Manajemen Strategis. Diterjemahkan Julianto Agung, Yogyakarta: Penerbit Andi, 2006.

Yusanto, Muhammad Ismail dan Widjayakusuma, M. Karebet. Manajemen Strategis Perspektif Syari'ah. Jakarta: Khairul Bayan, 2003. 